\title{
Colonisation and connectivity by intertidal limpets among New Zealand, Chatham and Sub-Antarctic Islands. I. Genetic connections
}

\author{
Sharyn J. Goldstien ${ }^{1, *}$, Neil J. Gemmell ${ }^{2}$, David R. Schiel ${ }^{1}$ \\ ${ }^{1}$ Marine Ecology Research Group, School of Biological Sciences, University of Canterbury, Private Bag 4800, \\ Christchurch, New Zealand \\ ${ }^{2}$ Centre for Reproduction and Genomics, Department of Anatomy and Structural Biology, University of Otago, PO Box 913, \\ Dunedin, New Zealand
}

\begin{abstract}
Limpets of the genus Cellana are important grazers in the intertidal zone throughout New Zealand and in many ways serve as models for understanding biogeographic patterns along heterogeneous coastlines. This genus is speciose in New Zealand, with some being widely distributed. The C. strigilis species complex in particular provides a good model for population connectivity because it is spread over the southern coast of New Zealand and throughout the Sub-Antarctic Islands, a region of complex hydrography from around $45^{\circ}$ to $52^{\circ}$ south latitude. In the present study we investigated genetic connectivity and phylogeographic structure of the C. strigilis complex from mainland New Zealand, the Chatham Islands and the Sub-Antarctic Islands using mitochondrial gene sequence data. Partial sequences from mitochondrial cytochrome $b, 12 \mathrm{~S}$ and $16 \mathrm{~S}$ genes revealed 2 genetic lineages that separate the Chatham, Bounty and Antipodes Island populations from the New Zealand mainland, Auckland and Campbell Island populations. Application of a relaxed molecular clock suggests that these lineages diverged 2 to 5 million years ago. The genetic homogeneity observed among populations of the 2 lineages, in conjunction with larval modelling, suggests that these populations are presently isolated but may have been colonised through long-distance dispersal from the southern island populations within the last $100000 \mathrm{yr}$. Alternatively, the lack of genetic differentiation may suggest that the populations experience ongoing bottleneck effects.
\end{abstract}

KEY WORDS: Marine phylogeography · Cellana · Marine biogeography $\cdot$ Long-distance dispersal · Vicariance $\cdot$ Biogeography

\section{INTRODUCTION}

Biota of the southern hemisphere play a central role in biogeographic studies, as trans-Tasman dispersal is often invoked to contest vicariance (i.e. isolation due to geological events such as ocean plate movement) as an explanation for the distribution of many southern hemisphere taxa, once thought to be of Gondwanan origins (Waters et al. 2000, Pole 2001, McDowall 2004, Sanmartin et al. 2007). More recently, the island status of New Zealand and the Chatham Islands has become pivotal in seeking support for the theory of long-dis- tance dispersal (LDD; Waters \& Craw 2006, Trewick et al. 2007). It has long been thought that dispersal is an important means by which the distribution of a species is extended or maintained and islands are colonised (Darwin 1859, McDowall 2004). However, the role of LDD or chance dispersal (Carlquist 1981, Trakhtenbrot et al. 2005) compared to that of vicariant isolation of populations across ocean basins is still a strongly debated issue (de Queiroz 2005). Studies involving plate tectonics initiated the vicariant movement (de Queiroz 2005), which in many instances replaced LDD theory with correlations of geological events to species 
isolations. However, the distributions of many species and genera across ocean basins do not necessarily correlate with known geological events. Furthermore, communities of sessile organisms are known to raft on algal drift or detritus influenced by strong winds and currents (Grantham et al. 2003, Gittenberger et al. 2006, Sanmartin et al. 2007). Many studies have therefore attempted to resolve these contrasting biogeographic theories.

The difficulties associated with resolving the biogeographic debate arise as much from ambiguous definitions as from the lack of time-travel. For instance, the term dispersal is itself ambiguous when used to describe a general phenomenon. Larval dispersal (e.g. planktonic transport) has quite different constraints than that of adult dispersal (e.g. rafting or hitchhiking). In addition, LDD theory, initially known as chance dispersal (Carlquist 1981), refers only to rare events that take a species beyond the borders of ecological or 'normal' dispersal distance by extraordinary means. In contrast, ecological LDD ability refers to the planktonic larval duration and dispersal potential of a species. Unfortunately, these terms are confused when biogeographers concerned with assemblage similarities across ocean basins use and interpret ecological studies related to population connectivity across ocean basins, and vice versa. Further confusion arises when phylogeographers (molecular ecologists) introduce terms such as genetic connectivity, gene flow and genetic structure, which all relate to the sharing of genetic information among populations, yet are too easily confused with dispersal among locations.

In the present study, we tested the population genetic structure of the Cellana strigilis species complex to investigate the link between genetic structure (sharing of genetic information) and population connectivity (dispersal among populations) among offshore islands (Chatham Islands and Sub-Antarctic Islands) and the mainland of New Zealand. Isolation of these populations is highly likely, considering the geology and hydrology of the region (Fig. 1). Geological evidence suggests that the Chatham Islands have been separated from New Zealand for approximately 70 million years (mya) (Emberson 1995) with transient islands potentially forming along the Chatham Rise (Scott \& Hall 2004), and more recent evidence suggests that the Chatham Islands were completely submerged during the Pliocene period, 1.8 to 2.4 million years ago (mya; Campbell 1998). The oceanic conditions of this region are complex and have in the past been influenced by glacial conditions (McGlone 2002, Carter et al. 2004). Today, the complexity arises through mixing of Sub-Tropical and Sub-Antarctic water (Fig. 1) along the Southland Front (Chiswell 2001) in combination with a net northeast flow and deep water eddies, which create meandering water masses above the Chatham Rise (Chiswell 1994, Neil \& Carter 2004). Simulations using satellite data suggest that it would typically take 30 to $50 \mathrm{~d}$ for larvae released off the east coast of mainland New Zealand to reach the Chatham Islands (Chiswell 2009, this issue). Therefore, organisms relying on larval transport would require an extended larval phase to reach the Chatham Islands, limiting connectivity between mainland New Zealand and the Chatham Islands to organisms with a longlived larval phase or a tolerance for long-distance rafting.

As geology and hydrology tend to isolate populations, gene flow and population connectivity among mainland New Zealand and the offshore islands is expected to be minimal. This expectation is supported by high species endemicity on the Chatham Islands (Emberson 1995). However, there are also many similarities between the Chatham Islands and New Zealand flora and fauna, suggesting recent population

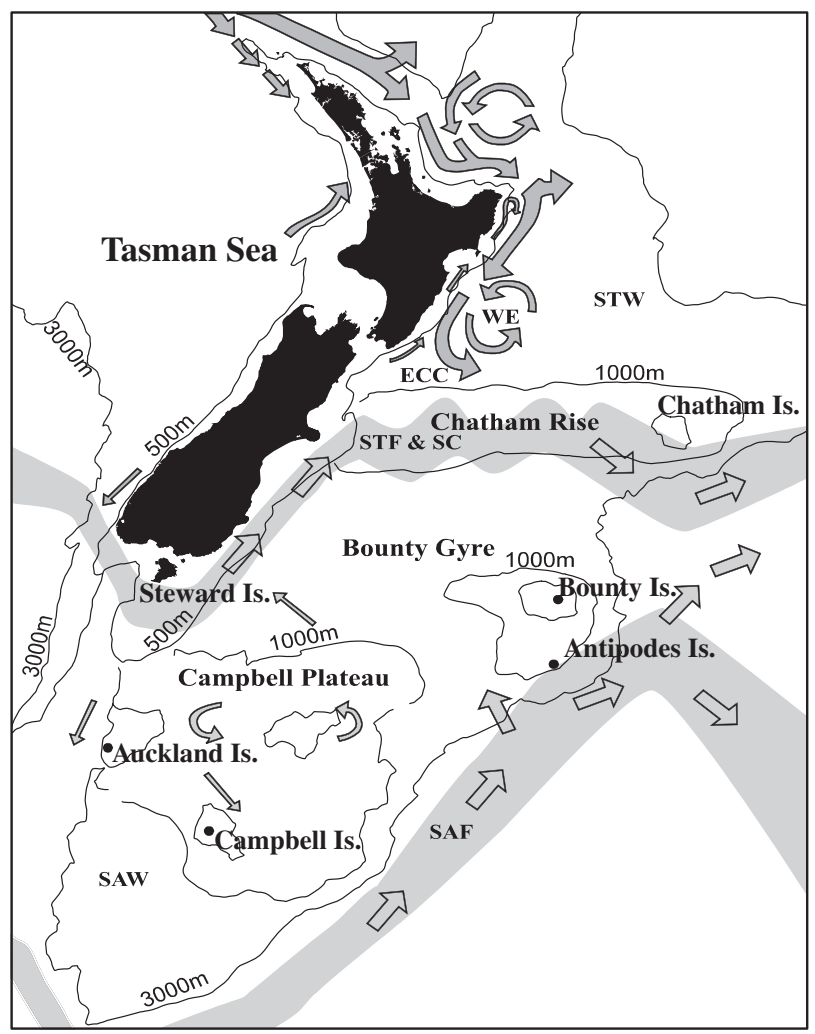

Fig. 1. Bathymetric and oceanographic features of the southern New Zealand sector of the Southwest Pacific Ocean. SAW: Sub-Antarctic water; SAF: Sub-Antarctic Front; STF: SubTropical Front; SC: Southland Current; STW: SubTropical water; WE: Wairapa Eddy; ECC: East Cape Current. Adapted from Chiswell (2001), Neil \& Carter (2004) and Wilson et al. (2005), and a figure by the National Institute of Water and Atmospheric Research. Bathymetric contours (black lines), major currents (arrows) and fronts (grey shading) are shown 
connectivity or New Zealand origins for Chatham Island taxa. These taxa include marine, terrestrial and freshwater organisms (Emberson 1995, Stevens \& Hogg 2004, McGaughran et al. 2006, Liggins et al. 2008).

In the present study 3 mitochondrial genes were used to assess the genetic structure of the Cellana strigilis complex from mainland New Zealand, the Chatham Islands and 4 Sub-Antarctic islands: Auckland Island, Campbell Island, Bounty Island, and Antipodes Island (Fig. 2). Mitochondrial gene sequences were analysed to test the genetic structure among mainland and island populations of C. strigilis ssp. We predicted that there would be significant genetic structure concordant with low gene flow, due to the limited dispersal potential of Cellana limpets and the oceanic isolation of populations of this species complex.

The intertidal Cellana limpets were used in the present study because they are ecologically important sedentary grazers (Dunmore \& Schiel 2003) with a short larval dispersal phase of only 3 to $10 \mathrm{~d}$ (Creese 1981). Cellana is mostly a tropical genus, but 6 species are distributed throughout New Zealand (Powell 1955, 1979). Previous phylogenetic studies (Goldstien et al. 2006b) have shown that Cellana is an ancient taxonomic unit within the Patelloida, with new species arising between 2 and 60 mya. The youngest of these is the $C$. strigilis complex of 2 to 5 mya, distributed only in the south of the South Island and the offshore islands of New Zealand (Fig. 2), and representing the most southern species of this genus (Powell 1979). The short dispersal period of the Cellana limpets is not conducive to LDD, such as the $850 \mathrm{~km}$ of ocean between mainland New Zealand and the Chatham Islands. For instance, significant genetic structure has been observed across ocean barriers $<200 \mathrm{~km}$ wide in Cellana limpet species of New Zealand and Hawai'i (Goldstien et al. 2006a, Bird et al. 2007). Furthermore, Cellana limpets graze on microalgae in the mid-high intertidal zone, where they are not usually associated with the macroalgal species commonly found as rafts in the Southern Ocean such as Durvillaea antarctica and Macrocystis pyrifera (Smith 2002).
The presence of Cellana limpets on the offshore islands (Chatham, Antipodes, Bounty, Auckland and Campbell Islands) and mainland New Zealand ('mainland' here referring to the South Island only) suggests that migration has or was occurring among these islands in some form, at some time, either now or in the past. However, the low dispersal potential and the low probability of rafting for this species suggests that land connections, or stepping stones, may have been necessary for the limpets to be so widely distributed. Previous phylogenetic studies have shown that C. strigilis chathamensis, the subspecies present on the Chatham Islands, has been isolated from mainland New Zealand C. s. redimiculum for approximately 2 to 5 my (Goldstien et al. 2006b). However, the genetic markers used in this study were species-level markers (i.e. slow

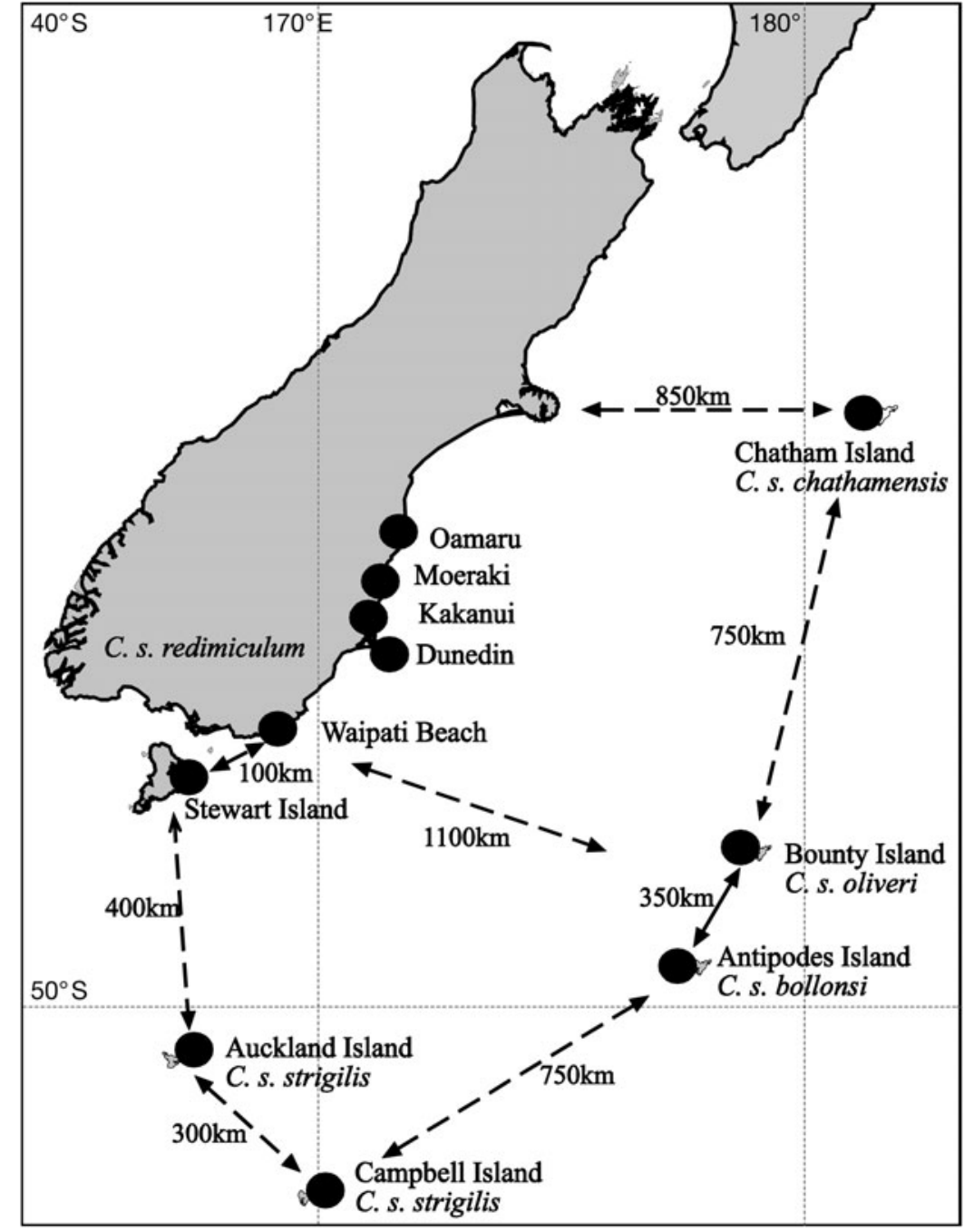

Fig. 2. Cellana strigilis ssp. Locations of subspecies of the C. strigilis complex sampled throughout southern mainland New Zealand, the Sub-Antarctic Islands and Chatham Island. The approximate minimum distances between islands are shown 
evolving) and would not be expected to show gene flow occurring since isolation of the subspecies. To explore the genetic relationships further and across a wider geographic area, we expanded the phylogenetic work to include a gene known to pick up intraspecific genetic structure in other Cellana limpets, across more recent (10000s of years) time scales and comparable ocean distances (Goldstien et al. 2006a, Bird et al. 2007). The inclusion of all subspecies in the $C$. strigilis complex from a wide range of islands also ensures a more robust test of genetic structure and population connectivity within this complex.

\section{MATERIALS AND METHODS}

Sampling. Cellana strigilis ssp. were collected from intertidal rocky reefs across their distribution (Fig. 2). Ten adults of each subspecies were collected from each location, and published sequences from 5 other species of Cellana not present on the offshore islands were used for phylogenetic comparisons in the present study (Table 1). Species identifications were based on shell morphology and soft tissue colouration (Powell 1979). Collections were made from November 2002 to February 2005 and specimens were preserved in $70 \%$ ethanol or frozen, depending on the logistics of transport from island populations.

For each specimen, a 3 to $5 \mathrm{~mm}^{2}$ section of muscle tissue was cut from the centre of the foot. The tissue was rinsed with distilled water and finely diced using flame- sterilised forceps and scissors. Diced tissue was then digested and purified following a modified lithium chloride/chloroform protocol (Gemmell \& Akiyama 1996) as described by Goldstien et al. (2006b).

Molecular methods. Partial sequences of the mitochondrial 12SrDNA and 16S rDNA genes were obtained from all 110 Cellana strigilis ssp. individuals collected, as per Goldstien et al. (2006b). The mitochondrial cytochrome $b$ gene was obtained using primers CytbKdegR (TCT CAG CAT GAT GAA AYT TY) and CytbFHdeg (GTC CTC AGG GTA GAA CAT AAC C), designed for the New Zealand limpet species C. flava (Hutton, 1873) (Goldstien et al. 2006a). PCR amplifications for cytochrome $b$ were done as described by Goldstien et al. (2006a).

PCR products were sequenced in both directions using the forward and reverse amplification primers for cytochrome $b, 12 \mathrm{~S}$ and 16S, using a Big Dye v. 3.1 sequencing kit (Applied Biosystems) as per the manufacturer's instructions. Sequence products were purified using Sephadex-GS50 gel filtration (Amersham Bioscience). Capillary separation of samples was performed either by the Allan Wilson Centre Genome Service on an ABI 3730 DNA analyser or the University of Canterbury Sequencing Service on an ABI 3100 DNA analyser.

Haplotypes were identified manually for each gene and aligned against reference sequences published for Cellana strigilis redimiculum (12S and $16 \mathrm{~S}$; Goldstien et al. 2006b) and $C$. ornata (cytochrome $b$; Goldstien et al. 2006a) using Bioedit v. 5.0.6 (Hall 1997). Haplotype reference sequences were deposited in the NCBI Gen-

Table 1. Cellana spp. Sampling locations, sample size and GenBank accession numbers for each of the species and subspecies used in this study. Cytb: cytochrome $b$

\begin{tabular}{|c|c|c|c|c|c|}
\hline \multirow[t]{2}{*}{ Species } & \multirow[t]{2}{*}{ Location } & \multirow[t]{2}{*}{$\mathrm{N}$} & \multicolumn{2}{|c|}{ GenBank accession no. } & \multirow[b]{2}{*}{ Cytb } \\
\hline & & & $12 \mathrm{~S}$ & $16 \mathrm{~S}$ & \\
\hline C. strigilis oliveri Powell, 1955 & Bounty Island & 10 & & & FJ882974 \\
\hline C. s. bollonsi Powell, 1955 & Antipodes Island & 10 & & & FJ882973 \\
\hline \multirow[t]{7}{*}{ C. s. redimiculum (Reeve, 1854) } & Moeraki & 10 & AY621808 & AY837760 & FJ882966 \\
\hline & Oamaru & 10 & & & \\
\hline & Dunedin & 10 & & & \\
\hline & Waipati Beach & 10 & & & FJ882967 \\
\hline & & & & & FJ882971 \\
\hline & Kakanui & 10 & & & FJ882969 \\
\hline & Stewart Island & 10 & & & FJ882968 \\
\hline \multirow[t]{2}{*}{ C. s. strigilis (Hombron \& Jacquinot, 1841) } & Auckland Island & 10 & AY627626 ${ }^{\mathrm{a}}$ & AY837757a & FJ882965 \\
\hline & Campbell Island & 10 & AY $627627^{\mathrm{a}}$ & AY837756 & FJ882970 \\
\hline \multirow[t]{2}{*}{ C. s. chathamensis (Pilsbry, 1891) } & Te One Bay & 10 & AY621806 & AY $837758^{a}$ & FJ882972 \\
\hline & Whangatete Inlet & 10 & AY621806 & AY837758 & \\
\hline C. ornata (Dilwyn, 1817) & Kaikoura & 1 & AY621812a & AY837754 & \\
\hline C. denticulata (Martyn, 1784) ${ }^{\mathrm{a}}$ & Kaikoura & 1 & AY $621807^{a}$ & AY837759a & \\
\hline C. flava (Hutton, 1873) & Kaikoura & 1 & AY621809 & AY837761 & \\
\hline C. radians (Gmelin, 1791) & Kaikoura & 1 & AY621811 ${ }^{a}$ & AY837762 a & \\
\hline C. stellifera (Gmelin, 1791) & Taupo Bay & 1 & AY $621810^{a}$ & $\mathrm{AY} 837760^{\mathrm{a}}$ & \\
\hline
\end{tabular}


Bank database (Table 1). The mitochondrial 12SrDNA and 16SrDNA genes were used for phylogenetic analysis because they are slow evolving and resolve to species and subspecies level only. Intraspecific variation cannot be observed with these genes. The cytochrome $b$ gene was used for phylogeographic analysis in which intraspecific genetic structure can be observed due to the increased mutation rate for this gene.

Phylogenetic analysis. Published $12 \mathrm{~S}$ and $16 \mathrm{~S}$ sequences for all New Zealand species of Cellana, including C. strigilis redimiculum, C. s. strigilis and C. s. chathamensis (Goldstien et al. 2006b) were aligned with $12 \mathrm{~S}$ and $16 \mathrm{~S}$ sequences obtained from C. strigilis ssp. collected in the present study for phylogenetic analysis (Table 1). C. ornata was used as the outgroup sequence based on previous phylogenetic relationships of this genus (Goldstien et al. 2006b). A maximum likelihood analysis with 1000 bootstrap replicates was run in PAUP*4.0b10 (Swofford 1998) using the TRN with Gamma (alpha $=0.5567$ ) evolutionary model selected using AIC criteria from Modeltest 3.7 (Posada \& Crandall 1998) on the combined data set of $12 \mathrm{~S}$ and $16 \mathrm{~S}$ genes. Bayesian analysis was also done using a $4 \times 4$ nucleotide model with gamma estimation for 100000 generations (25\% burn-in) in Mr Bayes (Huelsenbeck \& Ronquist 2001, Ronquist \& Huelsenbeck 2003). Stationarity in the data was observed in 2 independent runs, sampled every 10th generation, after 100000 generations. The genetic distance between C. strigilis ssp. and their most recent common ancestor (MRCA) was calculated using the maximum likelihood model, and the divergence time was estimated using published rates of sequence divergence for these genes in Cellana limpets (Koufopanou et al. 1999, Goldstien et al. 2006b).

Phylogeographic analysis. The cytochrome $b$ sequences from 110 ind. of Cellana strigilis ssp. were used to investigate geographic associations among this species complex (Table 1). A statistical parsimony network was constructed in TCS 1.18 (Clement et al. 2000) to determine the relationship among haplotypes and to clarify the relationship among the subspecies. The average genetic diversity was estimated using Nei's (1987) nucleotide diversity $(\pi)$ in MEGA v. 3.1 (Kumar et al. 2004).

\section{RESULTS}

\section{Phylogenetic analysis}

In total, $907 \mathrm{bp}$ of sequence was resolved for the mtDNA 16S (489 bp) and 12S (418 bp) genes from Cellana strigilis bollonsi and C. s. oliveri for a total of 20 ind. (Table 1). No genetic variation was observed between C. s. bollonsi and C. s. oliveri, so 1 reference sequence was used in the phylogenetic analyses. Maximum likelihood and Bayesian analyses confirmed the presence of 2 distinct C. strigilis lineages (Fig. 3). C. s. redimiculum from mainland New Zealand and C. $s$. strigilis from Auckland and Campbell Islands were genetically identical and formed 1 lineage (Lineage A, Fig. 3). The second lineage included C. s. chathamensis, C. s. bollonsi and C. s. oliveri, with no variation observed for these genes (Lineage B, Fig. 3). The 2 lineages are as divergent from each other as they are from the sister species C. denticulata (Martyn, 1784); neither the maximum likelihood nor the Bayesian approach could adequately resolve these 3 lineages (54\% support and $63 \%$ posterior probability).

The sequence divergence for the 2 Cellana strigilis lineages from the MRCA (M, Fig. 3) was 0.006 to 0.007 nucleotide changes per site (mean: 0.0065). Using the

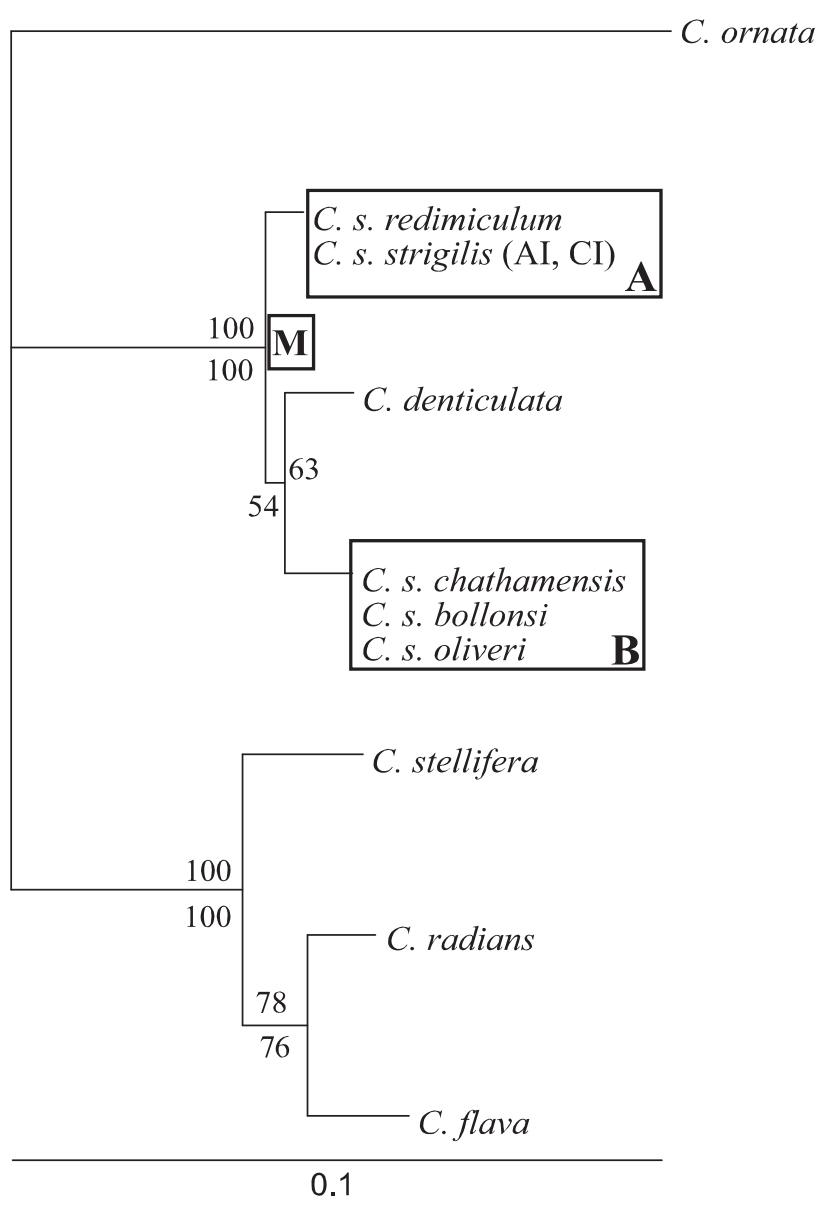

Fig. 3. Cellana spp. Phylogram of combined mitochondrial rDNA genes (12S and 16S) for New Zealand limpets of the genus Cellana. Bootstrap support (above branches) for maximum likelihood analysis and Bayesian support (below branches) are shown. Lineages A and B and the Most Recent Common Ancestor (M) are indicated as described in the text. C. strigilis strigilis was sampled from Auckland Islands (AI) and Campbell Island (CI). The scale bar represents the branch lengths as a measure of substitutions per site 
range of estimated rates $(0.0015,0.0012$ and 0.0026 substitutions per site per my) published for the genus Cellana (Goldstien et al. 2006b), an estimated time of sequence divergence for these lineages from the MRCA was 2.4 to 5.6 mya.

\section{Phylogeographic analysis}

A $360 \mathrm{bp}$ fragment of the mtDNA cytochrome $b$ gene was successfully amplified for a total of 110 ind., from the Cellana strigilis ssp. (Table 1), revealing 8 haplotypes among 11 populations (Fig. 4, haplotypes H1 to H8). No genetic variation was found among C. S. chathamensis, C. s. bollonsi and C. s. oliveri (Lineage B, Fig. 3) with each island population harbouring a single shared haplotype (Fig. 4, H8). Six of the 7 remaining haplotypes occur in the New Zealand mainland populations, with 1 of these expressed in all populations, including Auckland and Campbell Islands, at a frequency greater than $70 \%$ (Fig. 4, H1).

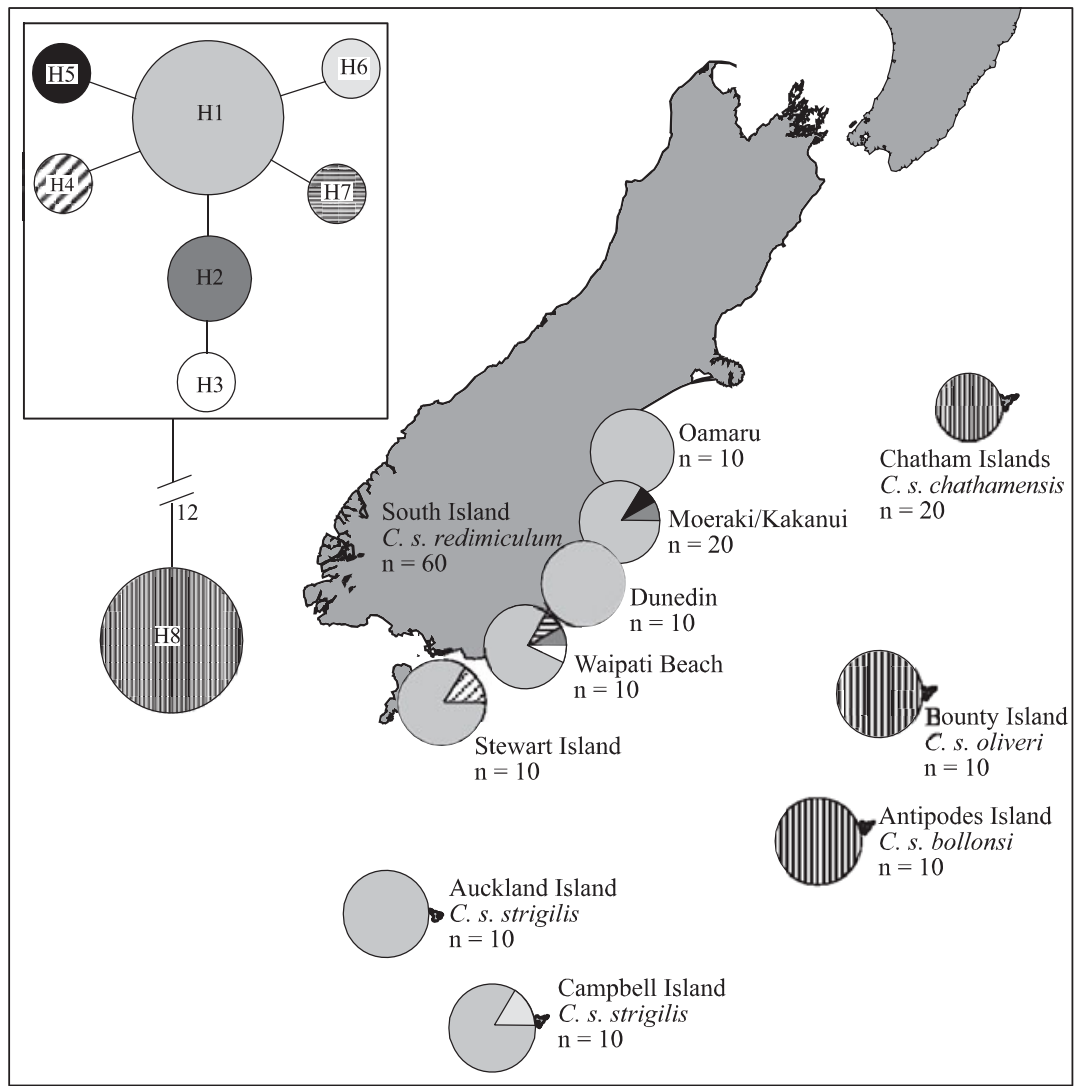

Fig. 4. Cellana strigilis ssp. Frequency distribution and statistical parsimony network for mtDNA cytochrome $b$ haplotypes of the $C$. strigilis complex throughout southern New Zealand, the Sub-Antarctic Islands and Chatham Island. Circles and portions are proportional to the haplotype frequencies within populations (distribution map) and for the total sampled (statistical parsimony network). Branches of the network represent 1 mutational step unless otherwise stated
One unique haplotype was observed in the Campbell Island population at a frequency of $20 \%$ (Fig. 4, H7). Despite the greater haplotype diversity observed on the mainland, the overall nucleotide diversity was low $(\pi: 0.013)$. The statistical parsimony network (Fig. 4) shows 12 mutational steps between $\mathrm{H} 8$ and the remaining haplotypes (H1 to H7). Therefore, a common ancestor cannot be assigned to these haplotypes due to the close relationship of the 7 claded haplotypes. The absence of ancestral haplotypes is due either to spatial or temporal sampling, which may include extinction, random genetic sampling, or lack of resolution of the data.

\section{DISCUSSION}

At an evolutionary time scale (millions of years), the Cellana strigilis complex comprises 2 divergent geographic lineages (Lineages A and B), with no evidence of gene flow between them. In addition to implications about spatial and temporal components of connectivity among these populations, the results suggest that taxonomic classification for this species complex needs to be readdressed.

The strong separation of these 2 lineages, based on the genetic structure observed, suggests that the limpet populations on the western (Lineage A) and eastern (Lineage B) islands have been isolated for 2 to 5 my and that this isolation is being maintained by present conditions preventing gene flow among populations. These results are concordant with geological and hydrological conditions of this region (Neil \& Treswick 2008), as well as the limited dispersal potential and low probability of LDD for this species complex. Re-connection of these populations or an LDD event would result in genetic homogeneity (i.e. at least 1 haplotype shared among the 2 lineages, or a haplotype[s] equally related to each of the lineages; Avise 2000). This was not seen in the genetic data, suggesting that complete population isolation is being maintained. Larval trajectory modelling supports population isolation among these island groups, with a minimum planktonic duration of 30 to $50 \mathrm{~d}$ required for 
larval dispersal to promote population connectivity between the mainland and Chatham Islands (Chiswell, 2009).

At a more contemporary time-scale (10 000 s of years) no genetic structure and low genetic diversity were observed within the 2 lineages. Genetic homogeneity was evident within the western lineage among subspecies sampled from mainland New Zealand, Auckland and Campbell Islands, where only 0.2 to $0.8 \%$ sequence divergence was observed among all populations. No genetic difference was found within the eastern lineage among subspecies from the Antipodes, Bounty and Chatham Islands.

'Genetic homogeneity' is used loosely to describe a large range of genetic similarities among populations, which prevents genetic structure being observed statistically. The absence of statistically significant genetic structure may result from a single common haplotype shared among populations to identical genetic makeup of populations. This breadth of homogeneity is one of the reasons that genetic similarities among populations can be maintained from as little as 1 migrant per generation (Slatkin 1987), and why LDD is often invoked. The data observed here show no genetic difference within the eastern lineage, and more importantly, there is only 1 haplotype representing a single maternal source, likely indicative of recent colonisation rather than genetic homogenisation through LDD. Chiswell (2009) used 15 yr of satellite data to simulate larval transport in the region. The simulated dispersal times between the islands can easily explain the separation of the 2 lineages, but are too long, except between Antipodes and Bounty Islands, to explain the observed homogeneity within the lineages. Chiswell suggests that rare LDD events, occurring too infrequently to be observed in $15 \mathrm{yr}$ of simulations, may influence the genetic connectivity, and the frequency of these events may be estimated by fitting analytical functions to observed histograms of larval dispersal.

A recent study on Duvillaea antarctica (Durvillaeaceae) found a similar lack of genetic differentiation among Sub-Antarctic Island populations (Fraser et al. 2009), which the authors attributed to recent colonisation after decimation of stocks from ice-scour during the Last Glacial Maximum (LGM). Such a scenario may have contributed, at least in theory, to the genetic homogeneity among populations within the 2 lineages identified in our study.

Sea conditions appear to have been considerably altered during the LGM when cold, dry, windy conditions prevailed in the southern islands region, and sea-surface temperatures (SST) were around 6 to $10^{\circ} \mathrm{C}$ lower than at present (Carter et al. 2004). Then, around 18000 years ago (ya), SST increased until
12000 ya when a short cooling period preceded the sustained warming from 11000 ya to present (McGlone 2002).

The tumultuous conditions in this region during the LGM may have created severe demographic bottlenecks in all populations of the Southern Ocean region, including the mainland and Sub-Antarctic Islands, most likely due to recruitment failure or adult mortality. The reduction in effective population sizes would create low genetic diversity, and the most common haplotypes would be more likely to survive, particularly if a selective advantage was associated with this haplotype and a selective sweep resulted (a neutral marker made abundant within a population due to an association with a locus under selection). Given the restricted distribution of this species complex compared to other Cellana species, it is possible that the $C$. strigilis ssp. are more susceptible to environmental change, which may be reflected in the population genetic structure and expression of ancestral polymorphism.

The population genetic structure seen in the present study highlights the difficulties involved in linking genetic structure with gene flow and population connectivity to understand the difference between 'dispersal' theory and vicariance. Several aspects of our data, in conjunction with larval simulations, suggest that the eastern islands were never connected to New Zealand and that this species complex has expanded from the south, and not from New Zealand as might first be considered. (1) The data show isolation among lineages of 2 to $5 \mathrm{my}$, which coincides with the suggested period of drowning of the Chatham Islands 1.8 to 2.4 mya (Campbell 1998), and may lend support to a vicariant split between New Zealand and Chatham Island populations millions of years ago. However, the appearance of more recent haplotypes due to the accumulation of neutral mutations (Kimura 1968), expected in the millions of years following such a demographic bottleneck, is not observed in the data. (2) The lack of genetic diversity within the lineages suggests that the populations are very young or are demographically unstable, with cycles of population collapse and expansion. High genetic diversity and recent genetic structure (hundreds of thousands of years) have been observed in the COI gene of other Cellana spp. (Goldstien et al. 2006a), so it is not unreasonable to expect a build-up of genetic diversity within this species under the assumption of stable growth over similar time periods. (3) Recent colonisation (less than hundreds of thousands of years) among the islands within each lineage could explain the genetic similarities and lack of genetic diversity observed in the data. However, the easterly flow and the long dispersal times among islands (Chiswell 2009) suggest that colonisation 
would have occurred due to an LDD event from the more southern islands tending northeast. This is highlighted by the low probability of arrival and the large number of simulations required for connections to occur within the dispersal time of Cellana larvae. The low probability of LDD driving the observed genetic connections is highlighted by a recent phylogeographic study of Durvillaea antarctica (Fraser et al. 2009). This large seaweed is commonly found as rafts in the Southern Ocean (Smith 2002); however, the study showed no genetic connections between New Zealand mainland, Chatham Islands and the SubAntarctic Islands (Fraser et al. 2009) in genes of similar evolutionary status to the COI gene used in the present study.

The genetic data presented here highlight the need for integration of oceanographic conditions and species ecology to more accurately interpret the genetic structure and population connectivity among populations and among species. Furthermore, assessing the influence of LDD and vicariance would be greatly assisted by the investigation of additional species distributed throughout the Southern Ocean.

Acknowledgements. We thank everyone who collected the samples from Stewart Island (B. Robertson and family), Chatham Islands (W. Nelson and V. Metcalf), Auckland Island (V. Metcalf), and Campbell, Antipodes and Bounty Islands (Mahalia Expedition). The Andrew W. Mellon Foundation of New York and the Foundation for Research, Science and Technology, New Zealand (Contract No. COIX0501) are gratefully acknowledged for financial support of this study. All Sub-Antarctic samples were collected under permission of the Department of Conservation, New Zealand, permit number SO-13905-FAU. We also acknowledge the enthusiasm and helpful input of S. Chiswell.

\section{LITERATURE CITED}

Avise JC (2000) Phylogeography: the history and formation of species. Harvard University Press, Cambridge, MA

Bird CE, Holland BS, Bowen BW, Toonen RJ (2007) Contrasting phylgoeography in three endemic Hawaiian limpets (Cellana spp.) with similar life histories. Mol Ecol 16: 3173-3186

Campbell HJ (1998) Fauna and flora of the Chatham Islands: less than 4MY old? In: Cooper R, Jones C (eds) Geology and genes, Vol MP 97. Institute of Geological and Nuclear Science, Wellington, p 15-16

Carlquist S (1981) Chance dispersal. Am Sci 69:509-516

> Carter RM, Gammon PR, Millwood L (2004) Glacial-interglacial (MIS 1-10) migrations of the subtropical front across ODP site 1119, Canterbury bight, Southwest Pacific Ocean. Mar Geol 205:29-58

Chiswell SM (1994) Variability in the sea surface temperature around New Zealand from AVHRR images. NZ J Mar Freshw Res 28:179-192

Chiswell SM (2001) Eddy energetics in the Subtropical front over the Chatham Rise, New Zealand. NZ J Mar Freshw Res 35:1-15
Chiswell SM (2009) Colonisation and connectivity by intertidal limpets among New Zealand, Chatham and SubAntarctic Islands. II. Oceanographic connections. Mar Ecol Prog Ser 388:121-135

Clement M, Posada D, Crandall KA (2000) TCS: a computer program to estimate gene genealogies. Mol Ecol 9: $1657-1660$

Creese RG (1981) Patterns of growth, longevity and recruitment of intertidal limpets in New South Wales. J Exp Mar Biol Ecol 51:145-171

Darwin C (1859) On the origin of species, Vol 1. Murray, London

de Queiroz A (2005) The resurrection of oceanic dispersal in historical biogeography. Trends Ecol Evol 20:68-73

Dunmore RA, Schiel DR (2003) Demography, competitive interactions and grazing effects of intertidal limpets in southern New Zealand. J Exp Mar Biol Ecol 288:17-38

Emberson RM (1995) The Chatham Islands beetle fauna and the age of separation of the Chatham Islands from New Zealand. N Z Entomol 18:1-7

Fraser C, Nikula R, Spencer HG, Waters J (2009) Kelp genes reveal effects of Sub-Antarctic sea ice during the Last Glacial Maximum. Proc Natl Acad Sci USA 106: 3249-3253

Gemmell NJ, Akiyama S (1996) A simple and efficient method for the extraction of DNA. Trends Genet 12:338-339

- Gittenberger E, Groenenberg S, Kokshoorn B, Preece R (2006) Molecular trails from hitch-hiking snails. Nature 439:409

Goldstien SJ, Gemmell NJ, Schiel DR (2006a) Comparative phylogeography of coastal limpets across a marine disjunction in New Zealand. Mol Ecol 15:3259-3268

Goldstien SJ, Gemmell NJ, Schiel DR (2006b) Molecular phylogenetics and biogeography of the nacellid limpets of New Zealand (Mollusca: Patellogastropoda). Mol Phylogenet Evol 38:261-265

Grantham BA, Eckert GL, Shanks AL (2003) Dispersal potential of marine invertebrates in diverse habitats. Ecol Appl 13:108-116

Hall T (1997) BioEdit v. 5.0.6 BioEdit. Department of Microbiology, North Carolina State University, NC

Huelsenbeck J, Ronquist F (2001) MR BAYES: Bayesian inference of phylogeny. Bioinformatics 17:754-755

Kimura M (1968) Evolutionary rate at the molecular level. Nature 217:624-626

Koufopanou V, Reid DG, Ridgway SA, Thomas RH (1999) A molecular phylogeny of the patellid limpets (Gastropoda: Patellidae) and its implication for the origins of their antitropical distribution. Mol Phylogenet Evol 11:138-156

Kumar S, Tamura K, Nei M (2004) MEGA3: integrated software of molecular evolutionary genetics analysis and sequence alignment. Brief Bioinform 5:150-163

Liggins L, Chapple D, Daugherty C, Ritchie P (2008) Origin and post-colonization evolution of the Chatham Islands skink (Oligosoma nigriplantare nigriplantare). Mol Ecol 17:3290-3305

McDowall RM (2004) What biogeography is: a place for process. J Biogeogr 31:345-351

> McGaughran A, Hogg ID, Stevens MI, Chadderton WL, Winterbourn MJ (2006) Genetic divergence of three freshwater isopod species from southern New Zealand. J Biogeogr 33:23-30

McGlone M (2002) The late quaternary peat, vegetation and climate history of the Southern Oceanic islands of New Zealand. Quat Sci Rev 21:683-707

Nei M (1987) Molecular evolutionary genetics. Columbia University Press, New York, NY 
Neil HL, Carter L (2004) Thermal isolation of Campbell Plateau, New Zealand, by the Antarctic Circumpolar Current over the past 130 kyr. Paleoceanography 19: PA4008

Neil V, Treswick S (2008) The age and origin of the Pacific islands: a geological overview. Philos Trans R Soc Lond 363:3292-3308

Pole M (2001) Can long-distance dispersal be inferred from the New Zealand plant fossil record? Aust J Bot 49: 357-366

Posada D, Crandall KA (1998) Modeltest: testing the model of DNA substitution. Bioinformatics 14:817-818

Powell A (1955) Mollusca from the Southern Islands of New Zealand, Vol 15. DSIR, Wellington

Powell AWB (1979) New Zealand mollusca. Marine, land and freshwater shells, Vol 1. William Collins Publishers, Auckland

Ronquist F, Huelsenbeck JP (2003) MR BAYES 3: Bayesian phylogenetic inference under mixed models. Bioinformatics 19:1572-1574

Sanmartin I, Wanntorp L, Winkworth RC (2007) West Wind Drift revisited: testing for directional dispersal in the Southern Hemisphere using event-based tree fitting. J Biogeogr 34:398-416

Scott GH, Hall IR (2004) Planktonic foraminiferal evidence on late Pliocene-Quaternary near surface water masses at ODP site 1123B, northern Chatham Rise, east of New Zealand. Mar Geol 205:127-145

Editorial responsibility: Antony Underwood, Sydney, Australia
Slatkin M (1987) Gene flow and the geographic structure of natural populations. (mutation, genetic drift, and natural selection lead to genetic differentiation). Science 236:787-792

Smith SDA (2002) Kelp rafts in the Southern Ocean. Glob Ecol Biogeogr 11:67-69

Stevens MI, Hogg ID (2004) Population genetic structure of New Zealand's endemic corophiid amphipods: evidence for allopatric speciation. Biol J Linn Soc 81:119-133

Swofford DL (1998) PAUP*. Phylogenetic Analysis Using Parsimony ( ${ }^{*}$ and other methods). Version $4 \mathrm{~b} 10$. Sinauer Associates, Sunderland, MA

Trakhtenbrot A, Nathan R, Perry G, Richardson DM (2005) The importance of long-distance dispersal in biodiversity conservation. Divers Distrib 11:173-181

$>$ Trewick SA, Paterson AM, Campbell HJ (2007) Hello New Zealand. J Biogeogr 34:1-6

Waters JM, Craw D (2006) Goodbye Gondwana? New Zealand biogeography, geology, and the problem of circularity. Syst Biol 55:351-356

Waters JM, López JA, Wallis GP (2000) Molecular phylogenetics and biogeography of galaxiid fishes (Osteichthyes: Galaxiidae): dispersal, vicariance, and the position of Lepidogalaxias salamandroides. Syst Biol 49:777-795

Wilson K, Hayward BW, Sabaa AT, Scott GH, Kennett JP (2005) A one-million-year history of a north-south segment of the Subtropical Front, east of New Zealand. Paleoceanography 20:PA2004

Submitted: September 30, 2008; Accepted: April 5, 2009 Proofs received from author(s): July 23, 2009 